\title{
大学の見える化技術を活用した産学連携の技術循環モデルとその実践
}

\author{
高村 藤寿*1, 太田 順子*2，尾崎 光則 ${ }^{* 1}$ ，西澤 泉*1
}

\section{Technology circulation model of industry-university collaboration utilizing visualization technology of university and its practice}

\author{
Fujitoshi TAKAMURA ${ }^{* 1}$, Yoriko OHTA ${ }^{* 1,{ }^{* 2} \text { Komatsu Ltd. }}$, Mitsunori OZAKI ${ }^{* 1}$ and Izumi NISHIZAWA ${ }^{* 1}$ \\ 2-3-6 Akasaka, Minato-ku, Tokyo 107-8414, Japan
}

Received 1 March 2016

\begin{abstract}
In this paper, Technology Circulation Model is proposed as a new management method for companies with existing business domains that plan and execute industry-university collaborations to make innovations. Based on this model, we discuss concepts for effective planning and execution of industry-university collaborations through real cases. Technology Circulation means a flow of Science - Technology - Engineering - Manufacturing \& Services, then to Science again. We show the effectiveness of the framework of industry-university collaborations, in which; empirically used techniques are visualized, complicated phenomena are explained simply, new sciences are established, and current industrial technologies are made more sophisticated. By starting from visualization of currently used technologies, it becomes possible to execute efficient industry-university collaborations matching the directions of business needs and academic seeds.
\end{abstract}

Key words : Industry-university collaboration, Technology circulation model, Linear model, Chain-linked model, Innovation, Visualization, Established technologies

\section{1. 緒言}

産学連携の必要性・重要性が，企業・大学双方にとって高まってきている.

企業の立場では，例えば著者らは 2000 年代初めにそれまで行ってきたエレクトロニクス等，新規事業への多 角化を目指寸方向から本業回帰へ方針を転換し，多角化の先行研究を主に担ってきた研究部門を，本業の建設・ 鉱山機械や鍛圧機械等の産業機械向けに特化して，開発により近い開発研究を担う組織とする改革を行った. その結果として，先行研究部門の研究開発成果が実用化する割合は増えたが，一方で社内のリソースが限られ ることから，将来技術のための基盤研究を社内で実施する機能は相対的に縮小寸ることとなった.

また，著者らは，従来，エンジン，油圧機器，パワートレイン，パワーエレクトロニクス等の主要コンポー ネントを自社で開発・量産する自前主義をとって優位性のある商品(モノ)づくりを重視してきた，そのモノづく りに対する方針は今後も継続する一方で，2000 年代半ばから ICT を活用したサービス・ソリューションビジネ ス等が重要性を増して，必要な技術が多様化してきている．既報(高村他，2016)で報告したように，機能特化型 商品をベースとして, バリューチェーンの下流のサービス・ソリューションにも領域を拡げて顧客価值を創造 するビジネスモデルをとっているものである．その実現には，オープンイノベーションの観点で，従来は社内 に保有していなかった新規技術についても積極的に社外から取り入れて活用する協業が必要になってきた.

一方大学においては，機械製造業等の産業にとって重要な基盤技術分野の研究活動が縮小していることが，

\footnotetext{
No.16-00070 [DOI:10.1299/transjsme.16-00070], J-STAGE Advance Publication date : 7 October, 2016

${ }^{* 1}$ 正員，（株）小松製作所（广107-8414 東京都港区赤坂 2-3-6）

*2 （株）小松製作所

E-mail of corresponding author: yoriko_ohta@komatsu.co.jp
} 
基盤技術の技術革新や人材育成の面で大きな課題になっている．産業を維持・発展させるために重要な基盤技 術研究が大学で縮小していくことは, 企業にとってはもちろん, 大学にとっても, 大学の優れた技術や人材を 社会に役立てる使命の点から軽視できない問題である．この縮小傾向は，鋳造，溶接等の伝統的な基盤技術分 野の学科で特に顕著に見られる.これらの伝統的な研究分野は, 新しい分野に比べて技術革新の成果が見えに くく予算の確保が難しいため，大学や公的機関においても研究や教育カリキュラムの縮小が続いている. (日機 連, 2009) しかしながら, 産業界にとっては従来と変わらずに必要不可欠な技術であり, 人材の継続的な採用・ 育成も必要である．国の基盤研究に関する科学技術政策は時代によって変化もあり，必ずしも基盤研究分野に 必要な研究予算が確保できる保証はない，基盤技術の研究や人材育成の存続には，産業界として必要とする大 学の基盤研究分野の継続・育成に自ら協力・関与寸る必要がある.

さらに, 2002 年度の科学技術基本計画(第 2 期)以降, 国は運営費交付金の額を減らしており, 科学技術発展の ための重点化を意図として競争的資金を強化している．大学の研究者を対象にした研究資金である科研費の配 分も，国はテーマを絞り込んで重点配分する方向にあり，大学としては国のみならず企業等からも研究資金を 積極的に獲得して研究を進める必要性が高まっている. 2004 年度の国立大学の法人化以降，さらにその傾向は 強まっており，大学の研究予算における競争的資金の割合は現在まで増加の傾向にある. (NISTEP, 2014)

以上の背景で企業においても大学においても産学連携への機運が高まったことから, 著者らは, 2004 年度か ら複数の大学と包括連携を結ぶなど，積極的に産学連携を活用したイノベーションを推進してきた．企業と大 学の組織的な産学連携を行うことで, テーマ設定, 実施において大学の連携責任者としてアサインされた教授 がメンターとして積極的に関与すること，産学双方のトップによる定期的なチェック体制が整うこと等がキー となり，研究成果が商品や製造プロセスに採用される成功確率が上がってきている.

その取組みの中で，産学連携テーマとして特に大きな成果を出してきたのが大学の「科学」を活用した従来 技術の見える化である．従来の産学連携は，大学の先端技術を企業に導入して実用化するという枠組みが一般 的であったが，それに加えて，企業がすでに事業ドメインとしている既存技術を「見える化・可視化」して現 象を解明する枠組みが有効であることが実例を通じてわかってきた，その一部では，大学における伝統的な基 盤技術分野の研究者が，大きな役割を果たしている．これまで企業がノウハウとして保持してきた技術が，大 学によって現象が見える化されることで, 体系化・理論化・一般化されて新たな科学が確立し，そこからまた 新たな技術シーズが見出されるという効果も生まれている.

すでに確固とした事業ドメインを持っている企業においては，産学連携の目的は，新規事業の創出より，既 存事業における飛躍的なイノベーションであることが多い，その場合に効果的に機能するのは，既存技術を出 発点に原理の解明を軸としてイノベーションを行うマネジメント手法である. 本論文では, 既存技術から原理 を見出すことで飛躍的な既存事業のイノベーションを行う「技術循環モデル」を核とした産学連携の効果的な 新たな枠組みとその実践について論ずる.

\section{2. 産学連携とイノベーションプロセス}

産学連携においては，大学と企業が従来よりも積極的に双方のニーズ・シーズを共有して，いわゆる「現場」 に関わり，産業分野での実用化を目指したテーマを設定する必要があると著者らは考える．大学と企業は互い の特長を活か寸領域でテーマを見出し, 連携することが求められている. 本論文では, 大学と企業の特長に応 じた役割分担について，「技術循環モデル」を軸に論じる.

新規技術を実用化するイノベーションプロセスについては，これまでに「リニアモデル」と「連鎖モデル」 に大別されて議論されている. (Kline, 1992) リニアモデルは, 図 1 に示すようにイノベーションにおいて科学か ら技術，工学，製造が時系列で順番に発生するとしたモデルである．出発点が科学にあり，フィードバックの プロセスは入っていないのが特徴である.リニアモデルのプロセスには, 様々な障壁が存在するとされており, 米国国立標準技術研究所(NIST)による死の谷, ダーウィンの海(吉野, 2003)や, 吉川らによる第 2 種基礎研究に おける悪夢(吉川, 内藤, 2003), 出川らによる魔の川(出川, 田辺, 2006)等の提案がある. 図 2 に, 出川らによる これらのモデルの時間軸に沿った比較を示す. (出川, 田辺, 2006) いずれも, 新規技術を実用化するまでのフェ 一ズが移り変わる際の障壁に関するものである. 出川らによると, 魔の川は研究と開発のベクトルが異なるこ 
Takamura, Ohta, Ozaki and Nishizawa, Transactions of the JSME (in Japanese), Vol.82, No.842 (2016)

とに起因する障壁である。ここでは研究シーズを作り出す大学と開発ニーズを持つ企業の間に生じやすい認 識・目的のずれと解釈できる，次の死の谷は，技術シーズを事業化する段階で，開発から顧客視点に軸足を移 す際に生じる障壁とされる．NIST のモデルにおいては，主にベンチャ一企業を想定して，技術シーズを事業化 する際の資金不足による障壁と捉えられてきた。さらにダーウィンの海は，新製品が既存市場や競合企業との 競争の中で生き残り収益を上げるために必要な市場競争における障壁である．既存事業を持つ企業と大学にお ける産学連携を念頭に置くと, 死の谷とダーウィンの海は企業の内部で生じる障壁と位置づけられる.

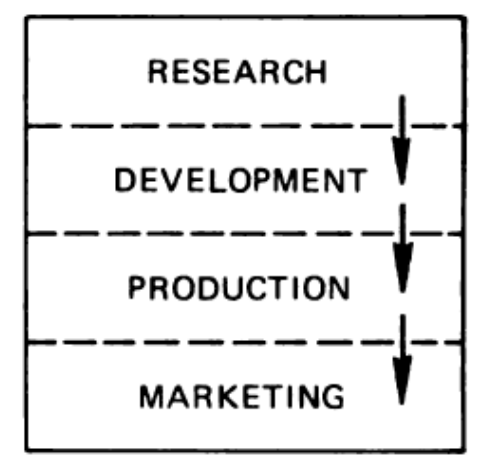

Fig. 1 Innovation process by linear model. (Kline and Rosenberg, 1986)

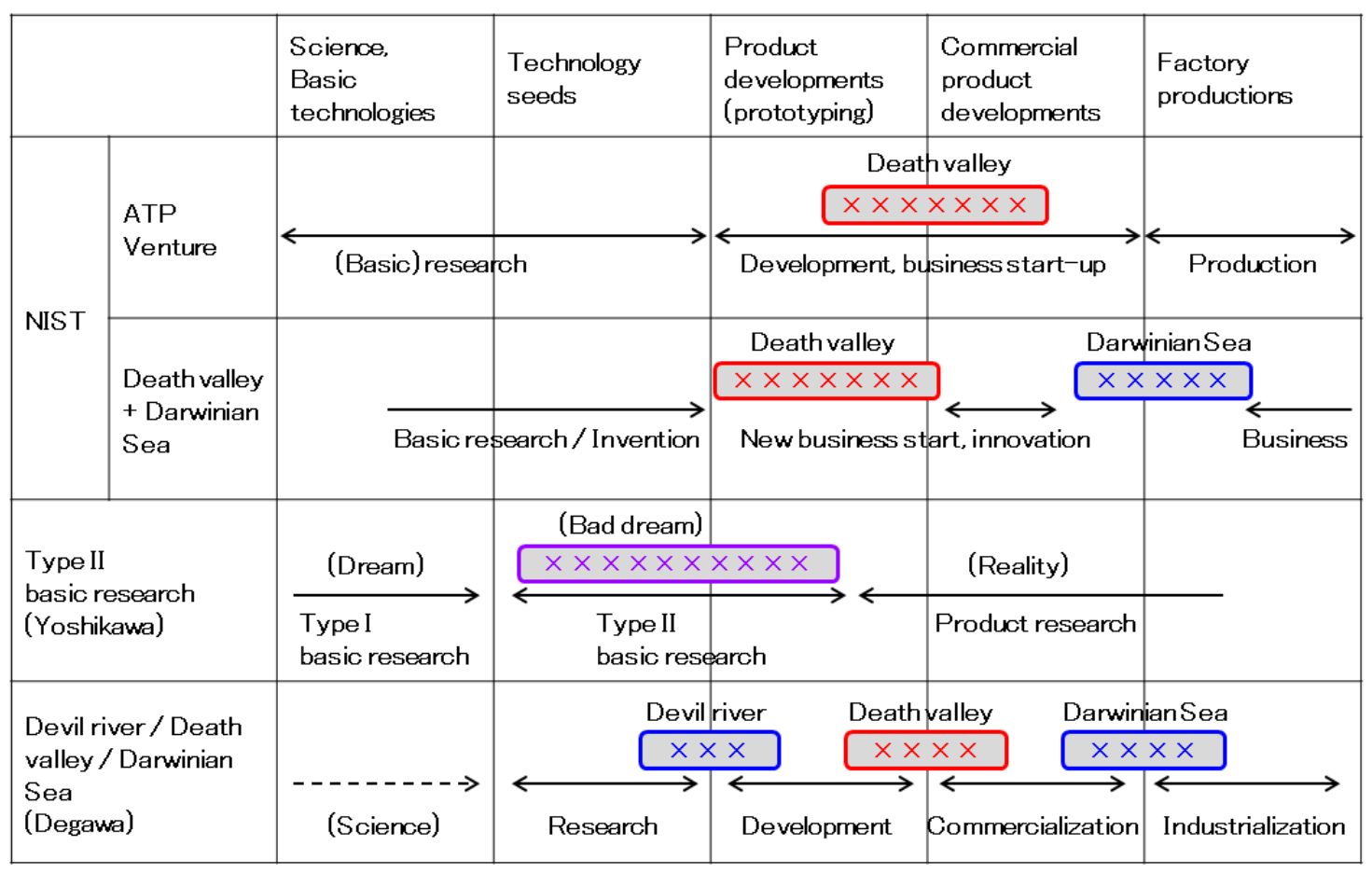

Fig.2 Comparison of positioning between various barriers in the innovation process of new technologies.

(Modified, Original chart: Degawa and Tanabe, 2006)

図 2 の各モデルにおいては，時間軸として，左から始まり右への完成形に向けた流れのみ考慮されている. 科学から始まり，技術シーズが生まれ，開発を経て，事業化に至るというリニアな流れである。これらは主に， ベンチャー企業を中心とする新規技術の事業化を念頭に考えられてきたモデルである.

一方で，連鎖モデルはリニアモデルでは十分にモデル化できない相互作用を取り入れることを Kline らが提唱 したモデルである. (Kline and Rosenberg, 1986)(Kline, 1992) リニアモデルでは時間軸がリニアになっているのに 
対して, 連鎖モデルは図 3 に示寸ようにイノベーションプロセスの各段階における多様な相互作用を考慮して いる．市場ニーズから発して設計，生産，販売，マーケティングへと至る企業の事業活動そのものがメインの プロセスとなっており，その各段階において蓄積された知識を活用，もしくは新たに研究によって必要な知識 を獲得・活用寸るためのサブプロセスを含んでいる．本モデルでは時間が一方向の単一の流れではなく，フィ ードバックプロセスも考慮されている．リニアモデルと比較して，多様なイノベーションプロセスが存在する 実態をより表したという点で優れたモデルと言われている. (小池, 2006)

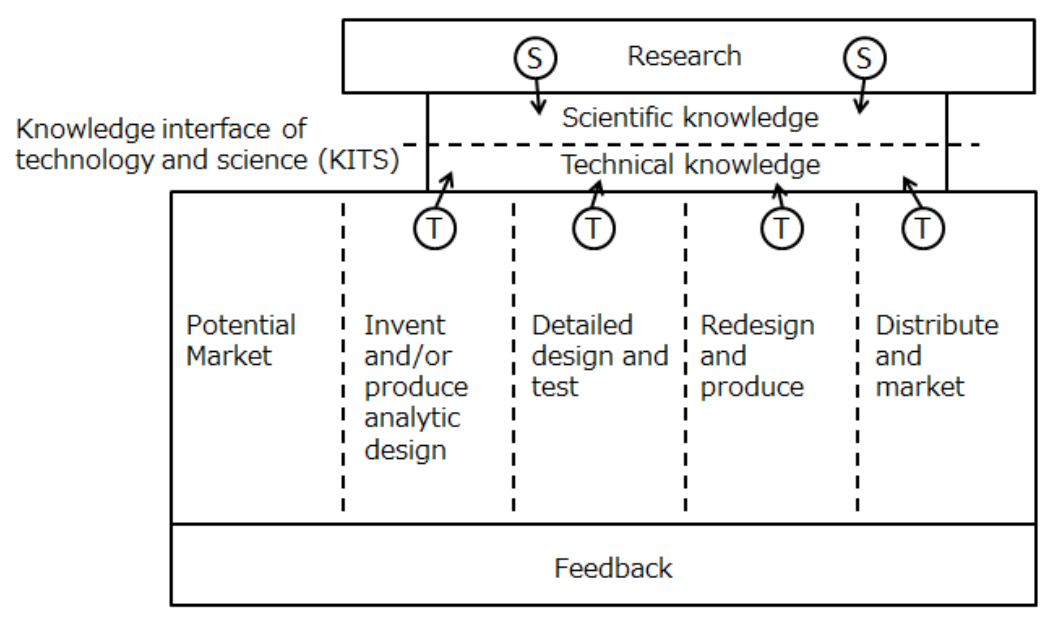

Fig.3 Kline’s revised chain-linked model. (Modified, Original chart: Kline, 1992)

連鎖モデルは蓄積されている知識を基盤にしてイノベーションを生み出していくプロセスで，研究は新たな 知識が必要とされたときに外側のプロセスとして投入される。研究成果はまた知識として蓄積された上でイノ ベーションプロセスに適宜利用されることになる. 連鎖モデルは Kline らが日本の製造業におけるイノベーショ ンプロセスを研究した結果考案したモデルであり, 従来型の日本企業におけるイノベーションの特徴に近い.

(Kline, 1992) 企業において実施されるイノベーションプロセスの実態に近い, 多様で複雑なプロセスを表現して いると言えるが，産学連携に焦点を当ててその効果的なマネジメントに利用するという点では産学連携の役割 が明示的でなく十分ではないと考えられる.

産学連携は一般的に企業内に不足する新しい技術を大学から取り入れて活用し事業に結びつける意図で実施 するものであり，そこにはプロセスの一部として研究が久かせない．既存の知識の応用であったとしても，企 業内で未活用の知識であれば企業で活用するためのアレンジが必要であり，研究要素が生まれる．著者らのよ うな摺り合わせ型(藤本，2003)の機械製造業では特にその傾向が強い，そのため，産学連携を主体にしたモデル においては研究がプロセスの一部である方が効果を説明しやすい.

また，産学連携においては Kline の連鎖モデルのように全てのプロセスにおいて研究(大学)が関わることは難 しい，連鎖モデルの形で研究が機能するのは，企業内の研究部門ならばありうることであるが，基礎研究と事 業化に近い部分の研究では異なる組織・機能が担っているのが一般的であり, 一つの組織で全ての研究機能を 担当するのは稀である．産学連携においても，大学は得意とする分野において研究の一部を担うと考えるのが 現実的である.

以上のような考えでイノベーションプロセスの中から産学連携に関わる特徵を抽出したのが，次章で著者ら が提案する技術循環モデルである.

\section{3. 技術循環モデルと産学連携}

図 4 に，著者らが本論文で提案する技術循環モデルを示す。ここで「技術循環」とは，科学 S(Science) $\rightarrow$ 技 術 T(Technology) $\rightarrow$ 工学 E(Engineering) $\rightarrow$ 製造\&サービス M\&S(Manufacturing \& Service) $\rightarrow$ 科学 S(Science)に 
循環する流れと定義している．主に産学連携でのイノベーションプロセスを念頭に，科学技術を実際の産業に 活用する際の考え方を，一方向でなく，産業からさらに科学技術に戻る循環をキーとしてモデル化したもので ある．製造業においても，商品であるモノを用いたサービスにビジネスの領域を拡げる例が増えているため， 産業の最終段階を製造とサービスの両方とここでは定義している.

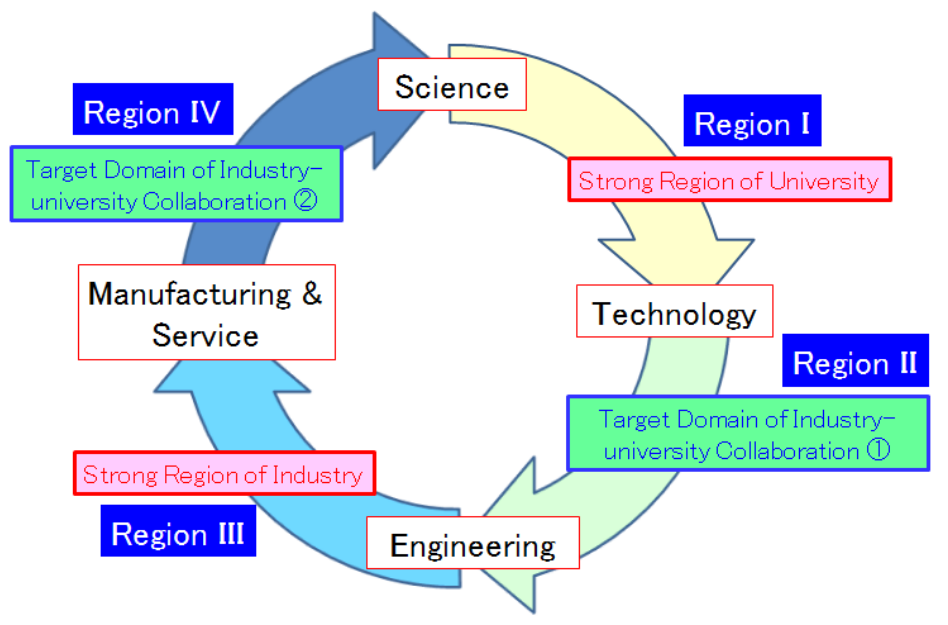

Fig.4 Technology circulation model.

本モデルは，連鎖モデルも考慮してリニアモデルに製造・サービスから研究に循環する流れを加えて拡張し たモデルと言える．本論文においては，技術循環モデルが産学連携をマネジメントする上での考え方や方向性 を提示するのに有効であることを，実際の産学連携テーマ事例を通じて立証する.

図 2 のリニアモデルにおける各種障壁との対応を, 出川のモデルを基に図 5 に示寸. 線形の時間軸ではなく, 製造\&サービス M\&S から科学 S に戻る流れがあり循環することが異なる. 3 種類の障壁は同様に存在すると考 えられるが，技術循環モデルを活用して既存技術を出発点とすることで，それを軽減できると考えている．主 に産学連携においての障壁の現れ方とその克服方法について, 著者らの考え方を技術循環モデルと関連付けて 後述する.

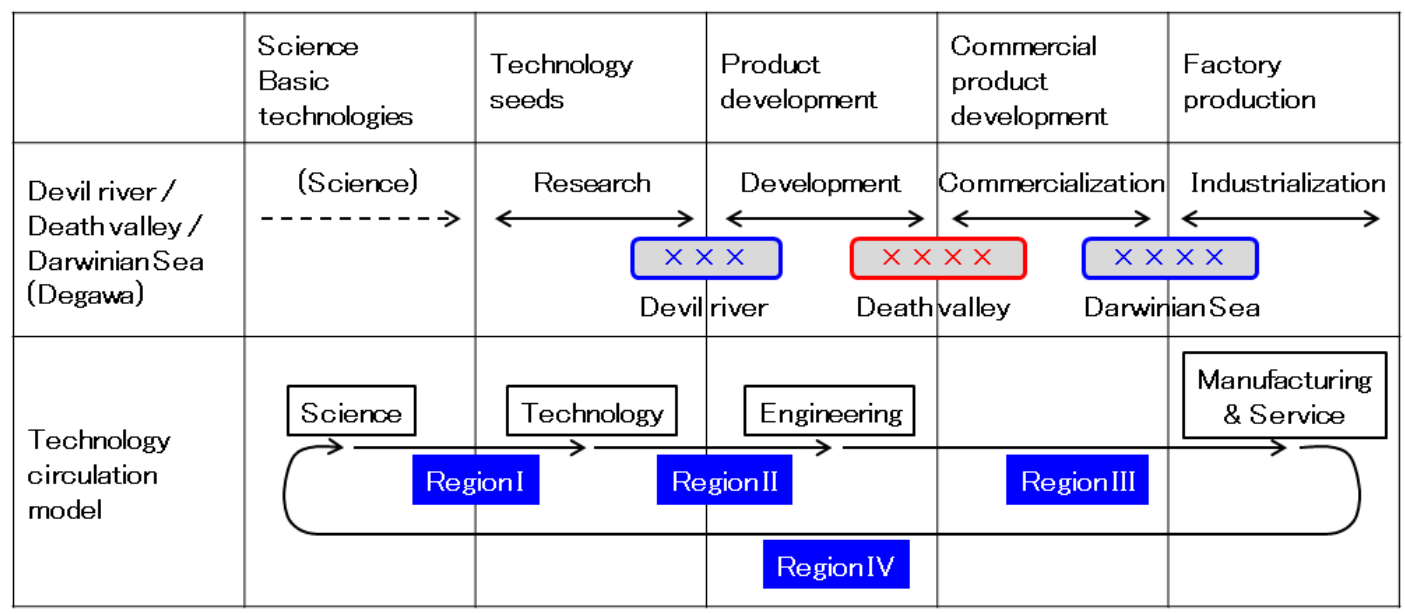

Fig.5 Correspondence of barriers between technology circulation model and the preceding model.

図 4 の科学 S から技術 T の流れ，時計の文字盤に見立てて 12 時 $\rightarrow 3$ 時の領域 $\mathrm{I}$ は,「科学で明らかにした原理 から『モノづくり』に適用する手段を見出すこと」と言える．科学から技術に至った段階で，初めて特許化が 
可能になる. 科学が産業に適用される第一歩である. 大学と企業それぞれの特長を考えると，この 12 時 $\rightarrow 3$ 時 の領域 I は大学に期待される領域である. 図 2 においては, Science, Basic technologies (=科学 S)から Technology seeds (二技術 T) に相当する.

次の技術 $\mathrm{T}$ から工学 $\mathrm{E}$ への流れ， 3 時 $\rightarrow 6$ 時の領域 II は，「先端技術・特許等を『モノづくり』としての開発 設計に向けて確立すること」である．技術を具体的な「モノ」として具現化するためには，技術の完成度を上 げて，確実性を持って使用できる条件を明らかにする必要がある，さらに，技術を組み合わせて，ある機能を 持った「モノ」として設計し，それを生産する手段を確立する。これは大学が作り上げた科学技術を産業に適 用するための最初の段階であり, 産学連携によって大学と企業が共に取り組むことで, 効率的に実現すること が期待される領域である. 図 2 では Technology seeds (=技術 T)から Product developments (=工学 E)に相当する. 従来の産学連携は, 多くがこの領域での取組みと解釈されてきた。この領域には, 出川らによって定義された 研究シーズと開発ニーズのベクトルの違いに起因寸る魔の川という障壁が存在すると解釈できる. (出川, 2004)

工学 $\mathrm{E}$ から製造\&サービス $\mathrm{M} \& \mathrm{~S}$ への流れ, 6 時 $\rightarrow 9$ 時の領域亚は,「確立した設計・生産技術を『モノづくり』 に適用すること」と言える，技術を織り込み組み合わせて作り上げた一個の「モノ」を，「商品」として開発し 量産する手段を確立していく段階である。この段階は産学連携の枠組みではなく企業が自ら取り組むべき領域 と考えられる. 図 2 では Product developments (=工学 E), Commercial product developments (=工学 E と製造\&节 ービス M\&S の中間), Factory productions (=製造\&サービス M\&S)の流れに相当し, 死の谷, ダーウィンの海と いう二つの障壁が存在することになる。 ベンチャー企業における死の谷，ダーウィンの海は，それぞれのフェ 一ズにおける外部資金の調達に関する障壁が主にクローズアップされるが，既存企業の内部においても，研究 開発部門から生産部門に担当が移行していく段階であり，各部門の役割による目的の違いから，スムーズに次 のフェーズに移行できない可能性があるという意味において障壁が生じることが考えられる．しかし，あくま で企業内で生じる障壁であり，本論文が対象とする産学連携とは直接の関係は少ないため，今後この二つの障 壁について詳細は論じないものとする.

以上の科学 $\mathrm{S} \rightarrow$ 技術 $\mathrm{T} \rightarrow$ 工学 $\mathrm{E} \rightarrow$ 製造\&サービス $\mathrm{M} \& \mathrm{~S}$ の 12 時 $\rightarrow 9$ 時の流れ(領域 $\mathrm{I} \sim \mathrm{III}$ )は, 従来から 言われてきた科学技術の産業適用の段階を一方向に再整理したものであり, 出川らが整理した図 2 とほぼ同じ 範囲を表現している.さらに著者らは, 主に産学連携における製造\&サービス M\&S から科学 S 々と戻る流れ, 9 時 $\rightarrow 12$ 時の領域IVの重要性に着目した。これは「優れた『モノづくり』から『現象を見える化』し，そこか ら原理を発見して『体系化，理論化，一般化』すること」である．なお，本論文では「見える化，可視化」は 大学の持つ先端的な計測・解析技術を用いて従来技術における現象を捉え，「体系化，理論化，一般化」のため のデータを獲得する過程と考えている，その後，データの中から普遍性や一般性を見出していく過程が「体系 化, 理論化, 一般化」であり, 最終的に科学的知見(科学 S)を得る. 9 時 $\rightarrow 12$ 時の領域IVは, 企業がモノづくり の中で経験的に培ってきた, 様々な機能を持った「モノ」「商品」を理論化して, 12 時の科学 $\mathrm{S}$ を新たに成立さ せる過程である.この製造\&サービス M\&S から科学 S への循環の流れを活用することが，産学連携では効果を 発揮する. 図 3 の連鎖モデルにおいては, 各段階からのフィードバックやメインプロセス(市場ニーズ〜設計〜 販売) と研究の間の情報の流れとこの循環の考え方が近い. 大学にとっては, このような企業ニーズを起点とし た技術循環の流れは，様々な社会的，学術的なニーズを受け入れる入口の一つと考えられる．大学はむろん別 の入口も持っており, 独自の関心で常に最新の学術的知見をブラッシュアップしている状態にあると捉えるこ とができるし, 産学連携においてはそれが大いに期待されている.この大学の機能と, 技術循環モデルの 9 時 を起点とする企業の従来技術に基づいたニーズというきっかけが結びつくと効果が高い.

企業が長年モノづくりを行い商品として市場に提供していく中では，様々な経験的ノウハウが蓄積され活用 されている，その中には，理論的には説明がついていないが，機能や信頼性が高いために広く利用されている というものが少なくない，これは図 3 の連鎖モデルにおいては，技術的知識に位置づけられており，イノベー ションにおいては技術的知識の創造と蓄積が重要であるとしている，確かに，技術的知識，経験的ノウハウは 企業の競争力の源泉であるが，一方でメカニズムが未解明のまま用いており，効果的に活用できていない可能 性も十分にある. 著者らは, 産学連携において, このような従来技術の現象を見える化・可視化して理論付け するテーマを広く対象としてきている．連鎖モデルで言えば，技術的知識と研究から新たに生まれた科学的知 識の境界面(KITS)での相互作用に注目したものと言える. 技術循環モデルでは, 連鎖モデルの技術的知識に相当 
Takamura, Ohta, Ozaki and Nishizawa, Transactions of the JSME (in Japanese), Vol.82, No.842 (2016)

する既存技術の経験的ノウハウを，積極的に研究にフィードバックする流れを重視する. その取り組みの結果， 企業におけるモノづくりから理論を見出して科学 $\mathrm{S}$ に立ち戻ることで，科学 $\mathrm{S} \rightarrow$ 技術 $\mathrm{T} \rightarrow$ 工学 $\mathrm{E} \rightarrow$ 製造\& サービス M\&S のサイクルをもう一度経て, より優れたモノづくりにステージを進める効果を得られることがわ かってきた.

企業の経験的ノウハウの中には，長年使用しており一定の信頼性があるため，変更することが容易ではない ものが少なくない. この場合も技術循環モデルは効果的である. 製造\&サービス M\&S から科学 S と戻る 9 時 $\rightarrow 12$ 時の流れ(領域IV)を経れば, 従来よりも有効かつ効率的な技術を新たに見出して, 理論的根拠をもって適用 することが可能となる.

以上の視点で提案した図 4 の技術循環モデルの中で, 産学連携の形を整理すると, 2 通りに分類することがで きる．一つは，科学 $\mathrm{S}$ と技術 $\mathrm{T}$ を具現化し，工学 $\mathrm{E}$ と製造\&サービス $\mathrm{M} \& \mathrm{~S}$ に結びつける従来行ってきた形（3 時 $\rightarrow 6$ 時の領域 II ）である.もう一つは，実績のある工学 E と製造\&サービス M\&S を大学の先端技術を活用し て見える化し，より目的に適った手段を見出していく形（9 時 $\rightarrow 12$ 時の領域IV）である. 技術循環モデルの中 では，この二つの領域での連携をうまく活用すると，大学と連携した企業のイノベーションが行いやすくなる と考えている.この二つの形で産学連携をおこなってきた事例に基づいて, 産学連携を企業, 大学双方にとっ て Win-Win の関係で成功に導くためのマネジメント手法としての技術循環モデルの有効性について, 次からの 章で分析・考察する.

\section{4. 産学連携テーマ成功事例分析}

本章では著者らがこれまでに行ってきた産学連携テーマ成功事例の中から, 図 4 の技術循環モデルの 3 時 $\rightarrow 6$ 時(領域 II ), 9 時 $\rightarrow 12$ 時(領域IV)のそれぞれに属するテーマの代表的な成功例を紹介し, 産学連携の 2 つの対象 領域の特徴とその成功要因を検討寸る. 6 時 $\rightarrow 9$ 時の領域亚はここでは産学連携の対象外と考えるため含まない が, 12 時 $\rightarrow 3$ 時の領域 I は 9 時 $\rightarrow 12$ 時(領域IV)から循環する次の段階として産学連携の流れの一部に組み込まれ ている.

\section{$4 \cdot 13$ 時 $\rightarrow 6$ 時 (領域 II) テーマ事例}

紹介寸る 2 事例について，技術循環モデルとの対応を表 1 に示寸． 2 事例は技術循環モデルの 3 時 $\rightarrow 6$ 時の領 域II(図 6)を対象に行ったものであり，それぞれの事例における段階がモデルのどの位置に相当するのかまとめ たものである. 詳細は各事例の中で説明する.

Table 1 Correspondence of region II subject case and technology circulation model.

\begin{tabular}{|l|l|l|}
\hline $\begin{array}{l}\text { Correspondence of technology } \\
\text { circulation model }\end{array}$ & $\begin{array}{l}\text { [1] Development of oblique } \\
\text { wavy surface heat exchanger }\end{array}$ & $\begin{array}{l}\text { [2] Soil behavior analysis } \\
\text { technology by DEM }\end{array}$ \\
\hline Three o' clock: Technology, T & $\begin{array}{l}\text { Heat transfer improvement } \\
\text { technology by oblique wavy } \\
\text { surface }\end{array}$ & Simulation technology : DEM \\
& $\begin{array}{l}\text { Fin shape optimization under } \\
\text { the environment using } \\
\text { construction machinery }\end{array}$ & $\begin{array}{l}\text { Algorithm improvements with } \\
\text { calculation accuracy and speed } \\
\text { to compare blade shapes }\end{array}$ \\
Six o' clock: Engineering, E & $\begin{array}{l}\text { Effect confirmation by heat } \\
\text { exchanger prototype for } \\
\text { construction machinery }\end{array}$ & $\begin{array}{l}\text { Establishment of soil behavior } \\
\text { analysis technology with high } \\
\text { reproducibility for blade designs }\end{array}$ \\
\hline
\end{tabular}




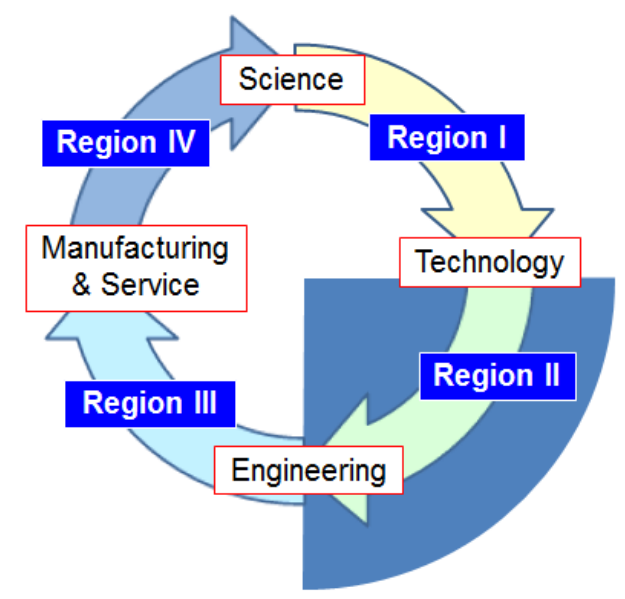

Fig.6 Region II in technology circulation model.

4・1・1 斜交波状フィン熱交換器の開発（Suzue et al., 2006)(鹿園, 2008)(福田, 鹿園, 2007)(鹿園他, 2010)

大学の研究者によるフィン壁面の斜交波状面化による伝熱促進効果に関する研究の成果を, 建設機械(建機) 用の熱交換器に適用して実用化した産学連携テーマである. 本技術は, 産学連携着手時にすでに大学で特許化 されており，建機以外の熱交換器用途への試みも行われていたが，建機特有の使用環境における効果が高い技 術であることが見出されたために，産学連携を開始して成果につながった。この技術を適用した建機用のラジ エータは，従来のものと同じ冷却性能を維持したまま小型化が可能である．建機の使用環境で問題となること の多い砂塵等の目詰まりによる性能劣化が従来よりも少ないため, 安定した性能を示す.ささらに, 冷却性能が 向上したことに伴って，ファン動力を低減できるため，騒音低減，燃費低減にも貢献している.

建機固有の使用環境における熱交換器のニーズは, 熱交換器前面風速が速いことと, 砂塵が多い作業環境に 曝されることである．建機は，低車速もしくは一定位置にとどまったまま稼動することが多いことから，自動 車とは異なり冷却用のファンで強制冷却している. そのため, 図 7 に示すように, 建機のラジエータ(産業用ラ ジエータの一種)は，層流域でも空調用や自動車用よりレイノルズ数の高い領域で稼動している.

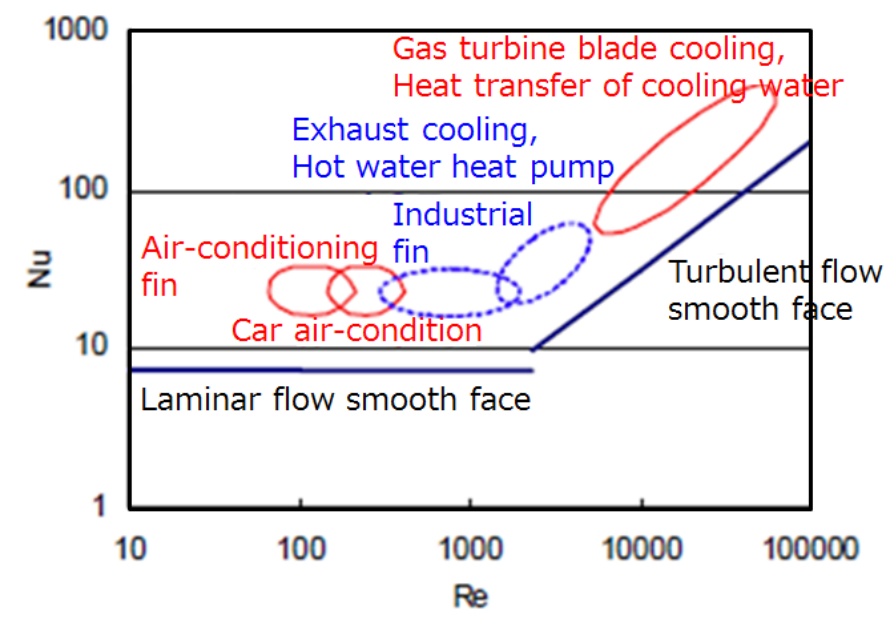

Fig.7 Positioning of construction machinery fin in heat transfer improvement technology. (Modified, Original chart: Shikazono, 2008)

本テーマでは, 表 1 に示すように, 大学においてシミュレーションと小規模モデル実験で高い効果が確認さ れていた斜交波状面による伝熱促進技術を技術 $\mathrm{T}$ として産学連携を開始し，建機の使用環境で高い放熱性と低 
い圧力損失を両立する斜交波状面の形状をシミュレーションで最適化するとともに，建機用熱交換器を試作し て, その効果を確認し工学 $\mathrm{E}$ とた. 本技術の適用は現時点ですでに 20 機種以上に及んでおり, 高い評価を得 て今後も引き続き拡大寸る予定である.

4・1 - 2 離散要素法(DEM)による土砂挙動解析技術 (Nakagawa et al., 2010)(Tsuji et al., 2012)(Tsuji et al., 2013) 建設・鉱山機械の一つであるブルドーザのブレード(排土板)は，土工作業を行うにあたってエンジン出力のう ちの多くのエネルギを消費し, 掘削・押土性能や燃費性能への影響度が高い装置である. しかし，土砂や岩石 と機械の相互作用は非常に複雑で, 解析・シミュレーションが困難であったため, 従来は主に経験に基づく設 計が行われてきた． 新規形状のブレードを開発するためには，模型試験と実験での作り込みに多大な時間と労 力がかかり，開発の効率化と期間短縮が課題であった.

本研究では, 表 1 に示すように大学が保有していた技術 T であるシミュレーション技術 DEM(Discrete Element Method, 離散要素法)を基にして, 付着性を有する土砂を物理法則に従ってモデル化し，押土・掘削シミュレー ションを行うブレード設計用の解析技術(工学 E)を開発した．この技術を開発用ツールとして実用化するのが最 終的な成果である．ブレードに対するモデル土砂粒径の小径化および計算速度向上の取組みを行うことで，作 業中の土砂の動きに関して，ブレード形状設計に適用可能な計算精度と速度を備えた大規模解析ができるよう になった．特に，それまで実験観測はもとより解析もできなかった土砂中のせん断破壊現象が可視化された成 果が大きい．加えて，ブレードに作用する力や各部面圧も計算できるようになった．従来の実験に比べて再現 性が高く繰り返しも容易であるため, 多くのアイデアを短期間に比較検討でき，ブレード形状設計が効率的に 行えるようになった．図 8 は DEM による掘削シミュレーションと，ガラス粒子と $1 / 20$ スケールブレードを用 いたベンチ実験を比較した例であり, 挙動が一致している. (Tsuji et al., 2013) シミュレーションでせん断帯が不 連続に形成される様子(図中 A, B)が可視化できるとともに, それに応じて粒子(土砂)が盛り上がってくる様子が, シミュレーションと実験の両方で確認できている.

本研究成果は, 関連する学会で表彰を受けるなど, 高い評価を得た. (Nakagawa et al., 2010) 企業内でも次世 代ブレード設計に活用を始めている.

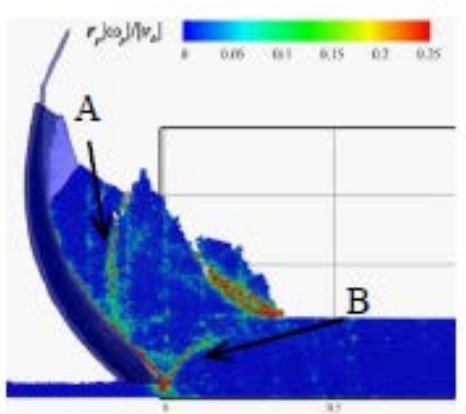

(a) DEM

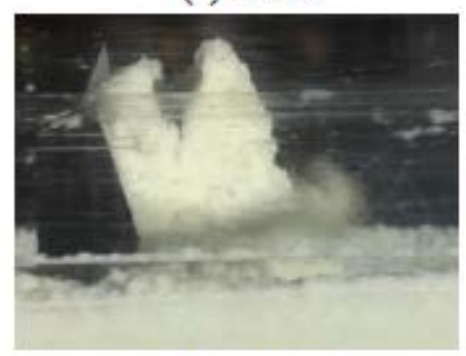

(b) Experiment

Fig.8 Comparison between DEM simulation and experiment in soil excavation. (A and B are shear band) (Tsuji et al., 2013) 


\section{$4 \cdot 29$ 時 $\rightarrow 12$ 時 (領域IV) テーマ事例}

紹介する 2 事例について，技術循環モデルとの対応を表 2 に示す。それぞれの事例における段階がモデルの どの位置に相当するのかについてまとめている．詳細は各事例の中で説明する．2 事例は技術循環モデルの 9 時 $\rightarrow 12$ 時の領域IVを対象に行ったものであり，その後 12 時 $\rightarrow 3$ 時の領域 I ， 3 時 $\rightarrow 6$ 時の領域 II まで到達して，6 時 $\rightarrow 9$ 時の領域III 企業内の実用化に達する効果を挙げている. 図 9 に示すように，技術循環モデルでは 9 時か ら 6 時までの広い領域で産学連携を行っていることになる.

Table 2 Correspondence of region IV subject case and technology circulation model.

\begin{tabular}{|l|l|l|}
\hline $\begin{array}{l}\text { Correspondence of technology } \\
\text { circulation model }\end{array}$ & $\begin{array}{l}\text { [1] Visualization of plasma } \\
\text { cutting phenomena }\end{array}$ & $\begin{array}{l}\text { [2] Visualization of large- } \\
\text { current welding phenomena }\end{array}$ \\
\hline $\begin{array}{l}\text { Nine o' clock : } \\
\text { Manufacturing \& Service, M\&S }\end{array}$ & $\begin{array}{l}\text { Longer operating life needs for } \\
\text { plasma processing machine } \\
\text { Visualization of droplet } \\
\text { evaporation phenomena }\end{array}$ & $\begin{array}{l}\text { Needs of increase in welding } \\
\text { rate } \\
\text { Visualization of droplet transfer } \\
\text { phenomena }\end{array}$ \\
Twelve o' clock : Science, S & Wear mechanism & Droplet transfer mechanism \\
Three o' clock: Technology, T & $\begin{array}{l}\text { Establishment of design } \\
\text { condition to control abnormal } \\
\text { wear }\end{array}$ & $\begin{array}{l}\text { Welding condition for good } \\
\text { droplet transfer form }\end{array}$ \\
Six o' clock: Engineering, E & Long life Hf electrode & $\begin{array}{l}\text { Devivation of optimum condition } \\
\text { MAG welding method }\end{array}$ \\
\hline
\end{tabular}

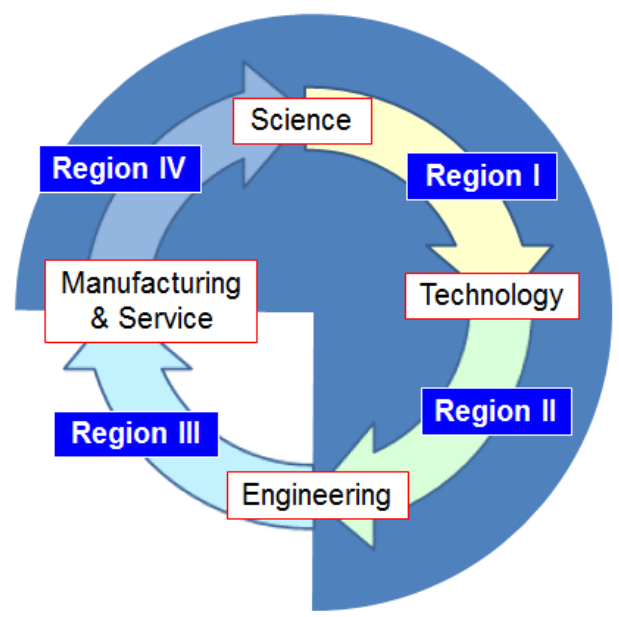

Fig.9 Implementing coverage of region IV industry-university joint research in technology circulation model.

4・2 -1 プラズマ切断現象の見える化（山口他, 2010)(山口他, 2011)(Long et al., 2012)(Long et al., 2013) 酸素プラズマ切断機は, 軟鋼の 6-32mm 程度の中厚板の切断用として広く用いられている. プラズマ切断では, 供給電流(切断電流)を増加することでより板厚の厚い鋼板を高速で切断可能となるが，一方で，消耗品であるプ ラズマトーチの Hf(ハフニウム)電極の寿命を短くする．従来の研究では，Hf 電極の消耗に関する寿命を予想す る損耗メカニズムは明らかになっていなかった，産学連携においては，大学の現象解明手法を活かしてプラズ マ加工機を長寿命化することを目的として，損耗速度に関する定量的なデータを収集すると共に，先行研究 (Peters et al., 2005)で提示されていた Hf 電極の液滴飛散現象をリアルタイム観測する見える化を図 10 のように行 
った. 図 10 には，これまでノズルに阻まれて観察できなかった Hf 電極の動作状態を, 観察空とカラー高速度 カメラで直接観察して, Hf 液滴が飛散する現象を捉えた様子を示している. 見える化の結果, 損耗現象が定常 損耗と異常損耗(液滴飛散現象)の足し合わせで起こるメカニズムが判明した. さらにそれを活用して異常損耗を 抑える設計を行うことによって, Hf 電極の長寿命化に成功した. その研究成果を報告した論文(山口他, 2010)は, 溶接学会論文賞を受賞して高い評価を受けた。

表 2 に示すように, 本テーマは 9 時のプラズマ加工機長寿命化ニーズから出発し, 9 時 $\rightarrow 12$ 時(領域IV)で液滴 飛散現象を可視化して損耗メカニズムを解明, それを受けた 12 時 $\rightarrow 3$ 時(領域 I )の異常損耗を抑える設計条件の 確立， 3 時 $\rightarrow 6$ 時(領域 II)の長寿命 Hf 電極実用化が実現した事例である. 9 時 $\rightarrow 12$ 時(領域IV)の現象解明から実 施した本テーマにおいては, 12 時 $\rightarrow 3$ 時(領域 $I$ ) も含めて大学と企業が常に連携して研究開発を行った. その後, 6 時 $\rightarrow 9$ 時の領域亚に関して企業内で開発を進め, 商品に織り込んだ．本テーマは現在も引き続き産学連携を続 けており，実験的な見える化に加えて，実験では見えない現象（固体である陰極と電磁流体のアークプラズマ の相互作用) の見える化シミュレーションにも取り組むことで(Long et al., 2012) (Long et al., 2013), さらなるレ ベルアップを目指して研究開発を進めている.

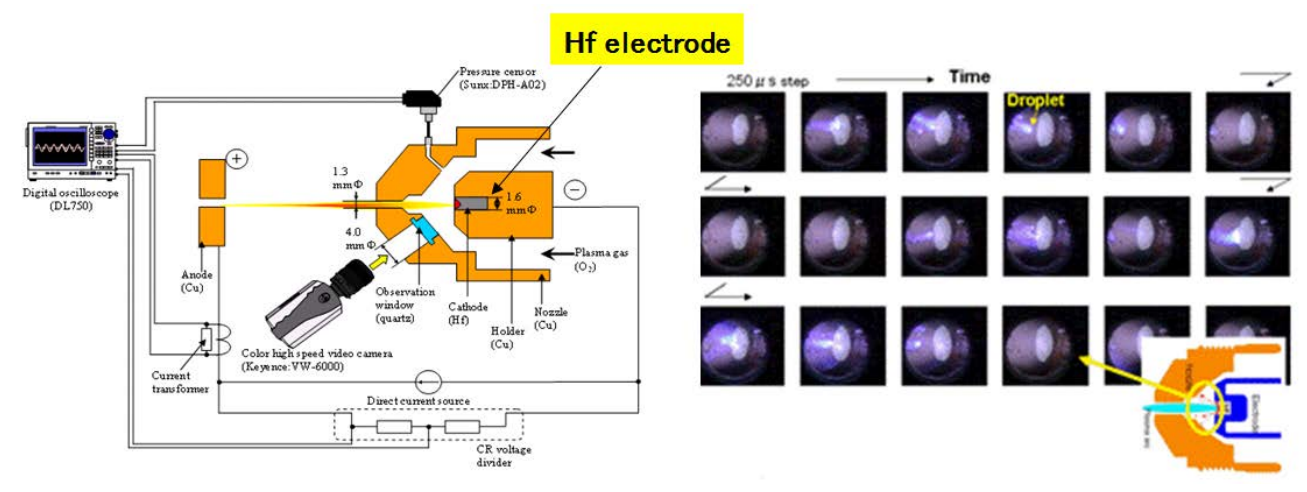

Fig.10 Visualization of Hf electrode wear phenomenon in plasma processing machine. (Yamaguchi et al., 2010)

\section{$4 \cdot 2 \cdot 2$ 大電流溶接現象の見える化（足立他, 2006)}

建機生産効率を高めるため, 溶接分野では溶着速度の向上が重要となる. しかしながら, 溶着速度を上げる キーとなる溶接電源は, 従来は市販の $500 \mathrm{~A}$ 溶接電源を使用し続けており, 技術革新が停滞していた. そこで, 従来の 2 倍の溶着速度を狙いとして, 産学連携によってオリジナルの $600 \mathrm{~A}, 700 \mathrm{~A}$ 溶接電源を開発して実際に 工場に導入し, 生産能力アップに貢献したというのが本事例である.

産学連携においては，大学の保有する計測技術やシミュレーション技術を活用して，従来困難であった大電 流溶接域のアーク現象を高速度カメラで撮影し, 大電流域での溶滴移行形態を可視化・見える化することに成 功した. 図 11 にその現象を捉えた写真を示す.さらに, 溶滴移行現象を解析して溶滴移行のシミュレーション モデルを構築し，安定化の方策を立案した。これらの知見をもとに，大学および溶接電源メーカと共同で，溶 接電源および溶接条件の改良を行い, 世界で初めての大電流マグ溶接法の開発に成功した. 表 2 に示すように, 9 時の溶接における溶着速度向上ニーズから出発し，9 時 $\rightarrow 12$ 時(領域IV)で溶滴移行現象を可視化してそのメカ ニズムを解明， 12 時 $\rightarrow 3$ 時(領域 I )のシミュレーションモデルの検討を経て，3 時として大電流においても良好 な溶接形態の得られる溶接条件が存在することを見出した.さらに, 3 時 $\rightarrow 6$ 時(領域 II)で最適条件の導出を行 って, 6 時の大電流マグ溶接法確立まで至ったものである. 本テーマにおいても，9時 $\rightarrow 6$ 時(領域IV〜II)の全て で大学と企業が連携して研究開発にあたった. その後, 6 時 $\rightarrow 9$ 時(領域亚)に相当する段階として, 企業におけ る量産ラインに適用し，生産能力向上に貢献した. 


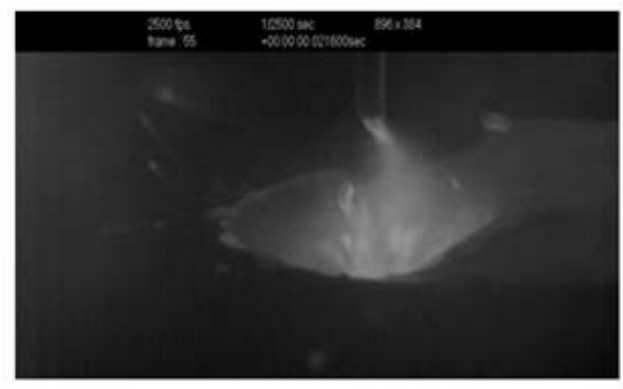

Large spatter generation by rotating transfer

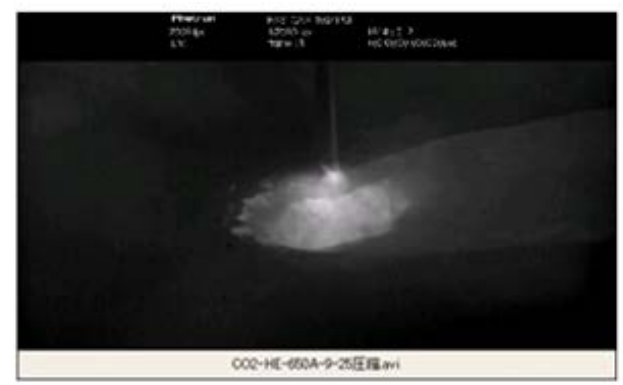

Stabilization of droplet transfer by modified power source and optimized condition

Fig.11 Visualization of droplet transfer phenomenon in large-current welding through high-speed camera technique.

\section{5. 技術循環モデルに基づく産学連携成功シナリオに関する考察}

ここでは，技術循環モデル(図 4)における 3 時 $\rightarrow 6$ 時(領域 II ), 9 時 $\rightarrow 12$ 時(領域IV)の二つの領域における産学 連携テーマの成功要因について考察し, 主に新たに位置づけて提案する後者の領域のテーマの成功確率の高さ について論ずる.

3 時 $\rightarrow 6$ 時(領域 II )の従来型の産学連携テーマは，大学がすでに保有していた技術 $\mathrm{T}$ を企業に導入して工学 $\mathrm{E}$ とする位置づけである，その際には，著者らの経験上，企業サイドから強いニーズと信念を持った担当者がア サインされ，大学サイドと企業サイドを強い関係で結びつけることで成功する確率が高まる傾向にある，それ ぞれが独自に作り上げてきた大学シーズと企業ニーズが連携着手時に完全に一致することは少なく, 実現のた めにはそのギャップを埋めるための障壁を乗り越える必要がある。これは，出川によって指摘されている図 2 の魔の川に相当する研究と開発のベクトルの不一致による障壁(出川, 2004)を，産学連携において正面から克服 する必要があることに相当する，一般に産学連携においては大学による技術シーズ集が用意されることが多い が，それだけでこの障壁を乗り越えるのは難しく，大学と企業双方がそれぞれの技術やニーズについて熟知し て判断を下せる目利き能力を鍛えることがキーとなる.

$4 \cdot 1 \cdot 1$ で紹介した「斜交波状フィン熱交換器の開発」テーマは，包括連携の責任者である大学教授と企業の 産学連携担当マネージャによる技術の目利きがきっかけとなり，共同研究を開始した．建機の排ガス規制対応 のためにエンジン冷却負荷が増大し，ラジエータの冷却性能向上が望まれているタイミングであり，大学シー ズと企業ニーズがマッチングした例である，共同研究実施段階においては，大学と企業のテーマ担当者が，建 機適用のための課題・目標を共有して実物での効果実証まで粘り強く進めたため, 建機の量産品適用にまで到 達することができた. このように, 3 時 $\rightarrow 6$ 時(領域 II )の産学連携テーマは, 大学シーズと企業ニーズの一致, それを見極める目利きの存在，大学と企業の担当者の強い協力体制が揃うことによって障壁を克服して，成果 を得ることができると言える.

一方, 9 時 $\rightarrow 12$ 時(領域IV)の従来技術の現象解明から出発する場合, 大学の見える化技術によって科学 S が判 明すると, 最初に従来技術の課題を共有した状態から開始しているため, 大学と企業がベクトルを一致させて 12 時 $\rightarrow 3$ 時(領域 I ), 3 時 $\rightarrow 6$ 時(領域 II ) 一と進めることができ, 成功の可能性が比較的高くなると考えられる. 大学は，それぞれの専門分野において広いネットワークを持って最新の技術的知見を保持している状態にある ため, そこに企業からの具体的なニーズというきっかけを得て, 現象解明を効率的に進められるのみならず, 新たな気づきがあった場合には，関連した新しい知見を引っ張ってくることができる．現象の見える化による 気づきは，企業の研究者にも同様に良い刺激を与えて，新たな技術に対する受容性の高い状態に引き上げる. 大学と企業それぞれが独自のポテンシャルに基づいて新たな視点の技術的知見を持ち寄ることによって，それ までとは異なるステージに進化して，イノベーションを生み出す可能性が高まる.

例えば, $4 \cdot 2 \cdot 1$ で紹介した「プラズマ切断現象の見える化」のテーマでは，プラズマ切断機の技術レベルが 飽和した状況にあり，企業側担当者はそれに対する問題意識と将来ビジョンを持ってはいたが，解決する方策 を企業内で見出せていなかったことが出発点となっている．競合技術であるファイバーレーザ等のレベルも接 
近しており，強い研究ニーズがあった，そこで，大学との包括連携に基づいた双方の目利きの仲介を経て，大 学のプラズマ技術の専門家と共同研究を開始することになった．企業側担当者は研究，開発，事業化と一貫し て携わった業務経験があり, 産学連携においても明確な課題と目標を提示したため, 大学側担当者が持つ先端 技術と効果的に連携する方向付けをすることができた. さらにこのケースでは, 企業側担当者が社会人ドクタ ーコースの学生の立場で大学においても研究を分担することになったため, 連携がより強化されることとなっ た．この枠組みで運営したため, 従来技術の課題が企業と大学の間で常時共有されて連携が強化・促進され， 所期目的を達成する優れた成果が 6 時の工学 $\mathrm{E}$ として得られている. その後, 研究成果である解析・シミュレ ーション技術を設計・モノづくりに反映し，企業内で 6 時 $\rightarrow 9$ 時(領域III)のフェーズの実用化を行い，技術循環 が達成されている. また, 企業側担当者も成果を認められ, 学位を取得した. 企業側担当者の学位取得後も, 大学とは引き続き強い連携関係にあり, さらなるレベルアップを目指した研究を継続している.

従来の 3 時(技術 T)から始める産学連携では懸念される 3 時 $\rightarrow 6$ 時(領域 II )に存在する魔の川と呼ばれる障壁に ついても, 9 時(製造\&サービス M\&S)から始める場合は, 障壁の生じる前の段階から大学シーズと企業ニーズを 一致させた状態で行っていくため，障壁とはなりにくい．また，6時以降の企業内の実用化・事業化フェーズに おける死の谷, ダーウィンの海についても, 従来技術を出発点として生産・マーケティングサイドが最初から 関与しており，そのニーズを研究開始時点から織り込んで進めているため，スムーズに進む場合が多い。この ようにして，既存の製品やサービスの見える化から出発した産学連携テーマは，現象解明・理論化，それに基 づく新たな技術シーズ創出，実用化を目指した開発設計において企業ニーズと大学シーズのベクトルを一致さ せることで，既存事業のイノベーション実現という循環を果たすことができるのである．もちろん，このケー スにおいても，ベクトルを一致させるために実施期間の各フェーズで目標の共有や修正を必要に応じて行い， これまでに述べたような技術循環モデルに基づく産学連携成功シナリオの原則を担保しつつ実施することが重 要である.

他にも 9 時 $\rightarrow 12$ 時(領域IV)テーマが産学連携において有利な点が考えられる. 産学連携では, 大学の社会的使 命としての成果発表と企業秘密とのジレンマがしばしば課題となっている. しかし，12 時の科学 S を通る 9 時 $\rightarrow 12$ 時(領域IV)テーマは, 成果の一部が企業の実業から距離があるため成果発表を行いやすい側面があり, 大学 のメリットも大きい場合が多い.

そもそも，事業ドメインをすでに確立している企業がそのドメインで産学連携を行う場合は，たとえ 3 時 $\rightarrow 6$ 時(領域 II)で大学から新しいシーズを導入する場合においても，基本的に既存事業である 9 時から発生したニー ズがその動機となっていることが多い. 企業ニーズと大学シーズの一致が難しいケースが多いことを考慮する と, シーズを作り上げる 12 時 $\rightarrow 3$ 時(領域 I ) より前の段階から連携を始めることで, ベクトルを一致させて行う 方が近道になる場合も多いと考えられる. それが 9 時 $\rightarrow 12$ 時(領域IV)の産学連携テーマの有利な点と言える.

なお，技術循環モデルは既存事業を出発点としても，その小改善を䄈らっているものではない. 経験的に行 ってきた従来技術を体系化・理論化・一般化することで，飛躍的なイノベーションを実現することを叔らいと するものである. 先にも述べたように, 従来技術の現象の見える化によって, 大学と企業の技術に対する受容 性が高くなり，それまでとは異なる視点での体系化・理論化・一般化によって，従来とは異なるステージに進 む不連続なイノベーションを生み出す可能性も高くなる. 場合によっては, 一回のサイクルではイノベーショ ンを行うことが難しいテーマもあるかもしれないが，技術循環モデルを何度か回すことで，体系・理論が強化 されて飛躍的イノベーションの実現に近づけることができる.

以上で述べてきたように，産学連携テーマを技術循環モデルに基づいて二つに分類して位置づけると，それ ぞれの特徵に応じて, 成功シナリオを描くために留意するべき点がわかりやすくなる. 産学連携テーマのマネ ジメントにおいては，各テーマを分類した上で成功する条件が揃っていることをチェックし，テーマの企画や 実施段階での軌道修正等を行うべきである. 


\section{6. 結 言}

本論文では，産学連携でイノベーションを行うための新たな枠組みとしての技術循環モデルと，それに基づ いて効果的に産学連携を企画・実行するためのマネジメント手法について提案した．以下に本論文の論点をま とめる.

・企業にとってのイノベーションを大学と共に行うための産学連携のマネジメントの枠組みとして, 従来の モデルを改良した技術循環モデルを提案した．既存の事業ドメインに関する産学連携では，このモデルの 視点が有効である.

• 9 時 $\rightarrow 12$ 時の領域IV(従来技術の見える化 : 現象解明)における産学連携の有効性を新たに示した. 従来技術 の課題に対する明確な企業ニーズに沿った共同研究を行いやすいテーマであり, 成功の可能性が高くなる.

・従来の産学連携に多い 3 時 $\rightarrow 6$ 時の領域II (新規技術の導入)では，大学シーズと企業ニーズのマッチングと それを見極める目利き能力，大学・企業双方の研究担当者の強い協力体制が揃うことで成功確率を上げる ことができる.

\section{謝辞}

本論文の執筆にあたって, 福井工業大学教授／大阪大学名誉教授の片岡勲先生から大学の立場からの産学連 携の考え方について多くの知見と助言をいただいたことに感謝する. また，産学連携テーマ事例の大学・企業 双方の担当者には，本論文で取り上げることをご快諾いただき，謝意を表する．各事例の記述内容は，著者ら によるマネジメントの側面からの解採であり，学術的詳細は各参考文献をご参照いただきたい.

\section{文献}

足立浩隆, 堅田寛治, 平田好則, 大電流マグ溶接の溶滴移行現象, 溶接学会全国大会講演概要, Vol. 79 (2006), pp. $112-113$.

出川通，技術経営の考え方一MOT と開発ベンチャーの現場から，光文社新書 (2004).

出川通，田辺孝二，ベンチャー企業における「日本型死の谷」の考察(ベンチャー経営と政策), 研究・技術計画 学会年次学術大会講演要旨集 21st (2006), p. 1143.

藤本隆宏，能力構築競争一日本の自動車産業はなぜ強いのか, 中公新書 (2003).

福田健太郎, 鹿園直毅, 斜交波状面の伝熱促進効果に関寸る研究, 2007 年度日本冷凍空調学会年次大会講演論文 集, (2007), pp. 293-296.

Kline, S. J. and Rosenberg, N., An overview of innovation, In the positive sum strategy, National Academy Press (1986), pp. 275-304.

Kline, S. J., イノベーション・スタイル一日米の社会技術システム変革の相違一，アグネ承風社 (1992).

小池一成, 産学官連携による研究開発の課題一地域産業と大学による研究開発を中心に一, 地域政策研究, Vol. 8, No. 3 (2006), pp. 275-292.

Long, N. P., Katada, Y., Tanaka, Y., Uesugi, Y. and Yamaguchi, Y., Cathode diameter and operating parameter effects on hafnium cathode evaporation for oxygen plasma cutting arc, Journal of Physics D: Applied Physics, Vol. 45 (2012), pp. 435203-435300.

Long, N. P., Tanaka, Y., Uesugi, Y. and Yamaguchi, Y., Numerical investigation of the effect of cathode holder shape on hafnium cathode evaporation for an oxygen plasma cutting arc, Journal of Physics D: Applied Physics, Vol. 46 (2013), p. 224012.

Nakagawa, Y., Tsuji, T., Takayama, T., Matsumoto, N., Tanaka, T. and Kadono, Y., DEM simulation of cohesive soil-pushing behavior by bulldozer blade, Proceedings of the Joint 9th Asia-Pacific ISTVS Conference and Annual Meeting of Japanese Society for Terramechanics, No. 071 (2010).

科学技術・学術政策研究所, 科学技術の状況に係る総合的意識調査(NISTEP 定点調査 2013) (2014).

Peters, J., Yin, F., Borges, C., Heberlein, J. and Hackett, C., Erosion mechanisms of hafnium cathodes at high current, Journal of Physics D: Applied Physics, Vol. 38, No. 11 (2005), pp. 1781-1794.

鹿園直毅, 気液熱交換器の技術課題と研究動向, 第 48 回銅及び銅合金技術研究会講演大会講演概要集 (2008), pp. 44-45. 
鹿園直毅, 井上満, 澄野慎二, 斉藤雄介, 矢部充男, 斜交波状フィン熱交換器の試作評価, 第 47 回日本伝熱シ ンポジウム講演論文集 $(2010)$, p. 319.

Suzue, Y., Morimoto, K., Shikazono, N., Suzuki, Y. and Kasagi, N., High performance heat exchanger with oblique-wave walls, 13th International Heat Transfer Conference, Vol. 18 (2006).

高村藤寿，太田順子，西澤泉，現場志向に基づいた顧客価值創造のためのビジネスモデル，日本機械学会論文集， Vol. 82, No. 835 (2016), DOI: 10.1299/transjsme. 15-00360.

一般社団法人日本機械工業連合会，平成 20 年度 機械工業の基盤技術に関する研究開発動向調査一機械工業の基 盤技術に関する調査専門部会報告書一 (2009).

Tsuji, T., Nakagawa, Y., Matsumoto, N., Kadono, Y., Takayama, T. and Tanaka, T., 3-D DEM simulation of cohesive soil-pushing behavior by bulldozer blade, Journal of Terramechanics, Vol. 49, No. 1 (2012), pp. 37-47.

Tsuji, T., Matsui, Y., Nakagawa, Y., Kadono, Y. and Tanaka, T., DEM study on the interaction between cohesive granular materials and tools, POWDERS AND GRAINS 2013: Proceedings of the $7^{\text {th }}$ International Conference on Micromechanics of Granular Media, AIP Conference Proceedings, Vol. 1542 (2013), pp. 947-950.

山口義博, 吉田和記, 上杉喜彦, 田中康規, 森本茂夫, 箕西幹夫, 斉尾克男, 酸素プラズマ切断におけるハフニ ユウム電極損耗現象についての研究，溶接学会論文集，Vol. 28, No. 3 (2010), pp. 311-318.

山口義博, 吉田和記, 片田優介, 上杉喜彦, 田中康規, 切断用酸素プラズマトーチの電極現象の実験的考察, 溶 接学会論文集, Vol. 29, No. 1 (2011), pp. 10-17.

吉川弘之, 内藤耕, 第 2 種基礎研究一実用化につながる研究開発の新しい考え方一, 日経 BP 社 (2003).

吉野完， R\&D バブル崩壊後のハイテク開発戦略「死の谷」を越えて，知的資産創造，No. 5 (2003), pp. 80-97.

\section{References}

Adachi, H., Katada, K. and Hirata, Y., Metal transfer phenomena in high-current MAG welding, National Meeting of Japan Welding Society, Vol. 79 (2006), pp. 112-113 (in Japanese).

Degawa, T., Concept of technology management - From the field of MOT and development venture, Kobunsha (2004) (in Japanese).

Degawa, T. and Tanabe, K., Study of "Japanese-type death valley" in venture company - Venture management and policy, Proceedings of the Annual Conference of the Japan Society for Science Policy and Research Management, Vol. 21 (2006), pp. 1143-1146 (in Japanese).

Fujimoto, T., Capacity building competition - Why strong Japanese automobile industry, Chuko Shinsho (2003) (in Japanese).

Fukuda, K. and Shikazono, N., Investigation of heat transfer characteristics of oblique-wave surface, Proceedings of 2007 JSRAE annual conference (2007), pp. 293-296 (in Japanese).

Kline, S. J. and Rosenberg, N., An overview of innovation, In the positive sum strategy, National Academy Press (1986), pp. 275-304.

Kline, S. J., Innovation styles in Japan and the United States; cultural bases; implications for competitiveness, Agune-shofu-sha (1992) (in Japanese).

Koike, K., The problems of research and development resolved by the collaboration - Among universities, regional industries, and the government, Regional Policy Research, Vol. 8, No. 3 (2006), pp. 275-292 (in Japanese).

Long, N. P., Katada, Y., Tanaka, Y., Uesugi, Y. and Yamaguchi, Y., Cathode diameter and operating parameter effects on hafnium cathode evaporation for oxygen plasma cutting arc, Journal of Physics D: Applied Physics, Vol. 45 (2012), pp. 435203-435300.

Long, N. P., Tanaka, Y., Uesugi, Y. and Yamaguchi, Y., Numerical investigation of the effect of cathode holder shape on hafnium cathode evaporation for an oxygen plasma cutting arc, Journal of Physics D: Applied Physics, Vol. 46 (2013), p. 224012.

Nakagawa, Y., Tsuji, T., Takayama, T., Matsumoto, N., Tanaka, T. and Kadono, Y., DEM simulation of cohesive soil-pushing behavior by bulldozer blade, Proceedings of the Joint 9th Asia-Pacific ISTVS Conference and Annual Meeting of Japanese Society for Terramechanics, No. 071 (2010). 
National Institute of Science and Technology Policy, Analytical report for 2013 NISTEP expert survey on Japanese S\&T and innovation system (2013 NISTEP TEITEN survey) (2014) (in Japanese).

Peters, J., Yin, F., Borges, C., Heberlein, J. and Hackett, C., Erosion mechanisms of hafnium cathodes at high current, Journal of Physics D: Applied Physics, Vol. 38, No. 11 (2005), pp. 1781-1794.

Shikazono, N., Technology issues and research trends of the gas-liquid heat exchanger, 48th Meeting of Japan Research Institute for Advanced Copper-base Materials and Technologies (2008), pp. 44-45 (in Japanese).

Shikazono, N., Inoue, M., Sumino, S., Saito, Y. and Yabe, M., Experimental assessment of oblique wavy fin heat exchanger, 47th National Heat Transfer Symposium of Japan (2010), p. 319 (in Japanese).

Suzue, Y., Morimoto, K., Shikazono, N., Suzuki, Y. and Kasagi, N., High performance heat exchanger with oblique-wave walls, 13th International Heat Transfer Conference, Vol. 18 (2006).

Takamura, F., Ohta, Y. and Nishizawa, I., Jobsite oriented business model for customer value creation, Transactions of the JSME (in Japanese), Vol. 82, No. 835 (2016), DOI: 10.1299/transjsme. 15-00360.

The Japan Machinery Federation, Research and development trends survey on basic technology of the machinery industry for fiscal 2008 - Survey expert group report on basic technology of the machinery industry - (2009) (in Japanese).

Tsuji, T., Nakagawa, Y., Matsumoto, N., Kadono, Y., Takayama, T. and Tanaka, T., 3-D DEM simulation of cohesive soil-pushing behavior by bulldozer blade, Journal of Terramechanics, Vol. 49, No. 1 (2012), pp. 37-47.

Tsuji, T., Matsui, Y., Nakagawa, Y., Kadono, Y. and Tanaka, T., DEM study on the interaction between cohesive granular materials and tools, POWDERS AND GRAINS 2013: Proceedings of the 7th International Conference on Micromechanics of Granular Media, AIP Conference Proceedings, Vol. 1542 (2013), pp. 947-950.

Yamaguchi, Y., Yoshida, K., Uesugi, Y., Tanaka, Y., Morimoto, S., Minonishi, M. and Saio, K., Experimental study of erosion of hafnium electrodes for oxygen plasma arc cutting, Quarterly Journal of the Japan Welding Society, Vol.28, No.3 (2010), pp. 311-318(in Japanese).

Yamaguchi, Y., Yoshida, K., Uesugi, Y., Tanaka, Y. and Katada, Y., Experimental study of phenomena on electrode for oxygen plasma arc cutting torch, Quarterly Journal of the Japan Welding Society, Vol. 29, No. 1 (2011), pp. 10-17(in Japanese).

Yoshikawa, H., Type 2 basic research - A new concept of research and development leading to commercialization, Nikkei Business Publications (2003) (in Japanese).

Yoshino, H., High-tech development strategy after collapse of R \& D bubble - Beyond the "death valley", Knowledge creation and integration, Vol. 5 (2003), pp. 80-97 (in Japanese). 